are met, and they must be quite certain of this. From past experience, I fear that this is a forlorn hope unless trade union principles are adopted, with "closed shop," "blacklegs," and the rest of the horrors. I feel that the time has come when we must decide whether to carry on with a gradual decline in our standard of living and a gradual increase in our working hours and conditions, or to become a trade union and suffer the petty tyrannies and loss of selfrespect which that might entail. I see no half-way course. I wish I could.-I am, etc.,

Wyke Regis, Dorset.

\section{Maternity Care}

Ellis Parkinson

SiR,--In the Supplement of July 20 (p. 42) comment is made on certain difficulties arising in the Harrow area. I do not know whether the Edgware General Hospital is the hospital referred to, or if I am the obstetric consultant in question, but should this be the case certain statements are factually incorrect. First, in the practice of this hospital no expectant mother is ever "forbidden" to see her own general practitioner, even though duplication of antenatal care ensues. Secondly, I have never "refused to meet a deputation from the Division," but on the contrary have from time to time attended several committees for full discussion. The Honorary Secretary of the Harrow Division, whose attention was drawn to these facts, has informed me that his committee is unable to make any comment to me as I am not a member of the British Medical Association, but I feel sure that you would welcome an opportunity to correct any inadvertent misrepresentations.-I am, etc.,

Edgware, Middx.

E. AP I. ROSSER.

\section{Association Notices}

\section{PRIZE ESSAY COMPETITION FOR PROVISIONALLY REGISTERED PRACTITIONERS, 1958}

The Council of the British Medical Association is prepared to consider the award, in 1958, of prizes to provisionally registered practitioners for essays submitted in open competition. The subject of the essay is : "What I Have Learned from Contact with the Patient's Relatives."

Any provisionally registered practitioner in the pre-registration year at the time of submission of the essay is eligible to compete for a prize. No study or essay that has previously appeared in the medical press or elsewhere will be considered eligible for a prize.

If any question arises in reference to the eligibility of a candidate or the admissibility of his or her essay, the decision of the Council of the British Medical Association shall be final. Should the Council decide that no essay entered is of sufficient merit, no award will be made. At least one prize of $£ 50$ is offered. In determining the number of prizes to be awarded, the Council will take into consideration the number and standard of essays received.

Essays must not exceed 5,000 words, and must be typewritten or legibly written in the English language on foolscap paper, on one side only, must be unsigned, and must be accompanied by a note of the name and address of the entrant. Notice of entry for this competition is necessary and a form of application can be obtained from the undersigned.

Essays must be forwarded so as to reach the Secretary of the British Medical Association not later than January 31, 1958. Inquiries relative to the competition should be addressed to the Secretary, British Medical Association, B.M.A. House, Tavistock Square, London, W.C.1.

\section{SCHOLARSHIPS IN AID OF SCIENTIFIC RESEARCH}

The Council of the British Medical Association is prepared to receive applications for research scholarships as follows: an Ernest Hart Memorial Scholarship, of the value of $£ 300$; a Walter Dixon Scholarship, of the value of $£ 300$; four ordinary Research Scholarships, each of the value of $£ 200$.

The scholarships are given to candidates recommended by the Science Committee of the Association as qualified to undertake research in any subject (including State medicine) relating to the causation, prevention, or treatment of disease.

Each scholarship is tenable for one year, commencing on October 1, 1958. A current scholar may apply to be reappointed for a further year, though no scholarship will be renewed more than twice. A scholar is not necessarily required to devote the whole of his or her time to the work of research, but may be a member of H.M. Forces or may hold a junior appointment at a university, medical school, or hospital, provided the duties of such appointment will not, in the opinion of the Science Committee, interfere with his or her work as a scholar.

Applications for scholarships, including renewals, must be made not later than March 1, 1958, on the prescribed form, a copy of which will be supplied by me on request. Applicants are required to furnish the names of three referees who are competent to speak as to their capacity for the research contemplated.

\section{SIR CHARLES HASTINGS AND CHARLES OLIVER HAWTHORNE CLINICAL PRIZES, 1958}

The Sir Charles Hastings Clinical Prize Competition is established by the Association for the promotion of systematic observation, research, and record in general practice. The competition has been extended by the addition of a second prize known as the Charles Oliver Hawthorne Clinical Prize. The following are the regulations governing the awards :

1. The Sir Charles Hastings Clinical Prize, consisting of a certificate and $£ 75$, will be awarded for the best entry.

2. The Charles Oliver Hawthorne Clinical Prize, consisting of a certificate and $£ 50$, will be awarded for the second best entry.

3. Any member of the Association who is engaged in general practice is eligible to compete for these prizes.

4. The work submitted must include personal observations and experiences collected by the candidate in general practice, and a high order of excellence will be required. If no work entered is of sufficient merit, no award will be made. Candidates in their entries should confine their attention to their own observations in practice rather than to comments on previously published work on the subject, though reference to current literature should not be omitted when it bears directly on their results, their interpretations, and their conclusions.

5. Essays, or whatever form the candidate desires his work to take, must be sent to the Secretary, British Medical Association, B.M.A. House, Tavistock Square, London, W.C.1, not later than December 31, 1957.

6. A prizewinner in any year is eligible for an award of either of the prizes itl any subsequent year. A study or essay that has been published in the medical press or elsewhere will not be considered eligible for a prize, and a contribution offered in one year cannot be accepted in any subsequent year unless it includes evidence of further work.

7. If any question arises in reference to the eligibility of the candidate or the admissibility of his or her entry, the decision of the Council on any such point shall be final.

8. Preliminary notice of entry for this competition is required, on a form of application to be obtained from the Secretary.

9. Each entry, which should be unsigned, must be typewritten or printed on one side of the paper only and accompanied by a separate note of the candidate's name and address.

10. No definite limits are laid down as to the length of the work submitted, but the Council anticipates that for this competition 3,000 to 10,000 words would be suitable.

11. Inquiries relative to the prizes should be addressed to the Secretary.

A. Macrae, Secretary.

\section{Diary of Central Meetings}

August

29 Thurs. Journal Committee, 2 p.m.

SEPTEMBER

18 Wed. Film Committee, 2 p.m.

19 Thurs. G.M.S. Committee, 10.30 a.m.

Correction.-Under the heading "Inflammable Clothing" in the report of the Annual Representative Meeting (Supplement, July 20 , p. 57) Dr. J. Atkinson was wrongly reported as referring to the British Ambulance Institute. This should have read British Standards Institution. 